\title{
Increased concentrations of inflammatory mediators in unstable angina: correlation with serum troponin $\mathrm{T}$
}

\author{
A Mazzone, S De Servi, I Mazzucchelli, I Bossi, E Ottini, M Vezzoli, F Meloni, \\ M Lotzinker, G Mariani
}

\begin{abstract}
Objective-To measure plasma interferon $\gamma$, monocyte chemotactic protein-1 (MCP-1), and interleukin 6 and to assess their correlation with cardiac troponin $\mathrm{T}$ in unstable angina.

Design-Blood sampling in patients undergoing coronary arteriography for known or suspected ischaemic heart disease.

Patients-76 patients divided in three groups: 29 with unstable angina (group 1), 28 with stable angina (group 2), and 19 without ischaemic heart disease and with angiographically normal coronary arteries (group 3).

Main outcome measures-Plasma interleukin 6 , interferon $\gamma, \mathrm{MCP}-1$, and troponin $\mathrm{T}$ in the three groups of patients.

Results-Interleukin 6 was increased in group 1 (median 2.19 (range 0.53-50.84) pg/ml) compared with the control group $(1.62(0.79-3.98) \mathrm{pg} / \mathrm{ml})(\mathrm{p}<0.005)$, whereas interferon $\gamma$ was higher in group 1 (range $0-5.51 \mathrm{pg} / \mathrm{ml}$ ) than in the other two groups (range $0-0.74 \mathrm{pg} / \mathrm{ml}$ and $0-0.37 \mathrm{pg} / \mathrm{ml} ; \mathrm{p}<0.005$ and $\mathrm{p}<0.001$, respectively). Patients with unstable angina (group 1) and positive troponin $\mathrm{T}$ had higher concentrations of interferon $\gamma$ than those with negative troponin $\mathrm{T}(0-5.51 \mathrm{pg} / \mathrm{ml} v 0-0.60 \mathrm{pg} / \mathrm{ml}, \mathrm{p}<0.001)$. Plasma MCP-1 was also higher in group 1 (median 267 (range 6-8670) pg/ml) than in the other two groups (134 (19-890) pg/ml and 84.5 (5-325) $\mathrm{pg} / \mathrm{ml} ; \mathrm{p}<0.005$ and $\mathrm{p}<0.001$, respectively), and among group 1 patients with a positive troponin $\mathrm{T}$ assay than in those with normal troponin $\mathrm{T}(531(14.5-8670) \mathrm{pg} / \mathrm{ml} v 69$ $(6-3333) \mathrm{pg} / \mathrm{ml} ; \mathrm{p}<0.01)$. There was no difference in plasma interleukin 6 in group 1 patients between those with and without raised troponin $\mathrm{T}$.

Conclusions-The inflammatory cytokines interferon $\gamma$ and MCP-1 are increased in patients with unstable angina, particularly in those with raised concentrations of troponin $\mathrm{T}$, suggesting that they are probably related to myocardial cell damage or to plaque rupture and thrombus formation. (Heart 2001;85:571-575)
\end{abstract}

Keywords: inflammatory cytokines; troponin $\mathrm{T}$; unstable angina

Istituto di Terapia

Medica e Nefrologia,

Policlinico S Matteo,

Pavia, Italy

A Mazzone

I Mazzucchelli

E Ottini

M Vezzoli

Dipartimento di

Cardiologia,

Policlinico S Matteo

S De Servi

I Bossi

G Mariani

Istituto di Malattie

Respiratorie,

Policlinico S Matteo

F Meloni

Istituto di Analisi

Biochimiche Cliniche,

Policlinico S Matteo

M Lotzinker

Correspondence to:

Dr Stefano De Servi, UO di

Cardiologia, Azienda

Ospedaliera "Ospedale Civile

di Legnano",

20025-Legnano, Italy

emodinamica.legnano@

calcol.it

Accepted 5 December 2000
Over the past two decades many experimental and human studies have examined the role of cytokines, chemoattractants, and adhesives molecules in the initiation, progression, and clinical emergence of the atherosclerotic plaque. ${ }^{1-9}$ These observations suggest that, whatever the initial stimuli (mechanical, chemical, infectious, or immunological), a continuous ongoing inflammatory process plays a role in the evolution of an uncomplicated atheromatous plaque into complex and vulnerable atheroma. Hallmarks of this evolving immune process are monocytemacrophage and lymphocyte cells, initially found in the fatty streaks and then playing a major role in plaque rupture and superimposed thrombosis. ${ }^{10}$ In acute coronary syndromes an increase in circulating activated lymphocytes, as well as of activated neutrophils, their inflammatory markers, and monocyte adhesion molecules, has been described. ${ }^{4}{ }^{11-15}$

Increased concentrations of interleukin 6 have been detected in patients with severe unstable angina and have been shown to be potent predictors of a poor short term outcome. ${ }^{16}$ However, the relation of interleukin 6 concentrations to troponin $\mathrm{T}$ in unstable angina has not yet been investigated. It is known that, independently of and in combination with increases in troponin $\mathrm{T}$ and troponin $\mathrm{I}$, interleukin 6 is the major determinant of the liver production of $\mathrm{C}$ reactive protein - an acute phase protein which, when raised in unstable angina, predicts a worse early outcome. ${ }^{17-20}$ It has also been found that C reactive protein is predictive of long term cardiovascular morbidity and mortality in patients with stable angina as well as in asymptomatic patients at risk of coronary artery disease. $^{2122}$

Activated $\mathrm{T}$ lymphocytes secrete interferon $\gamma$, a cytokine which interferes with the stability of the collagenous framework of the plaque's fibrous cap. ${ }^{10}$ On the one hand interferon $\gamma$ greatly decreases the synthesis of the interstitial forms of collagen from smooth muscle cells, while on the other hand it stimulates the formation and activation of macrophages, which accelerate the breakdown of both collagen and elastin. Moreover, this cytokine stimulates revascularisation and in situ thrombosis and impairs the ability of the endothelium to generate nitric oxide. ${ }^{10}$ Taken together, these processes are likely to affect the evolution of unstable coronary syndromes. ${ }^{10}$ 
Table 1 Baseline clinical and angiographic characteristics

\begin{tabular}{llll}
\hline & Group 1 $(n=29)$ & Group 2 $(n=28)$ & Group 3 $(n=19)$ \\
\hline Age (years) (mean (SD)) & $54(10.5)$ & $50(8.6)$ & $59(8.7)$ \\
Sex (M/F) & $24 / 5$ & $19 / 9$ & $10 / 9$ \\
Diabetes & $4(13.8 \%)$ & $2(7 \%)$ & 0 \\
Hypertension & $12(41.3 \%)$ & $7(25 \%)$ & $7(36.8 \%)$ \\
Hypercholesterolaemia & $12(41.3 \%)$ & $5(17.8 \%)$ & 0 \\
Current smokers & $10(34.5 \%)$ & $6(21 \%)$ & $8(42 \%)$ \\
Previous MI & $11(37.9 \%)$ & $6(21 \%)$ & 0 \\
Drug treatment & & & 0 \\
$\quad$ Aspirin & $24(82.7 \%)$ & $24(85.7 \%)$ & 0 \\
$\quad$ IV nitrates & $14(48.3 \%)$ & 0 & 0 \\
$\quad \beta$ Blockers & $13(44.8 \%)$ & $25(89.3 \%)$ & 0 \\
$\quad$ IV heparin & $10(34.5 \%)$ & 0 & 0 \\
$\quad$ Calcium antagonists & $19(65.5 \%)$ & $10(35.7 \%)$ & 0 \\
Coronary angiography & $8(27.5 \%)$ & $18(64 \%)$ & 0 \\
$\quad$ Single vessel disease & $21(72 \%)$ & $10(36 \%)$ & \\
$\quad$ Multiple vessel disease & & & \\
\hline
\end{tabular}

Values are $\mathrm{n}(\%)$ unless stated.

Group 1, unstable angina; group 2, stable angina; group 3, control; IV, intravenous; MI, myocardial infarction.

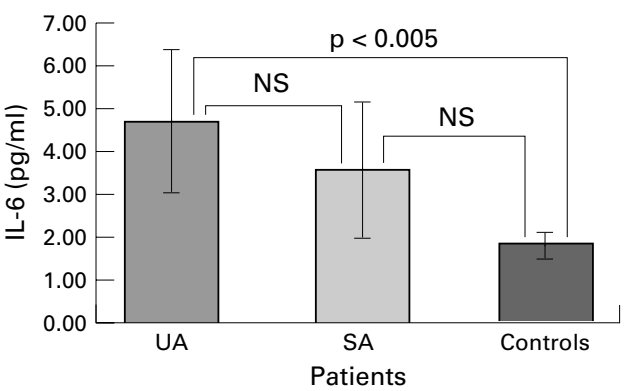

Figure 1 Interleukin 6 (IL-6) concentrations were higher in unstable angina (UA) than in controls. There was no difference between unstable angina and stable angina $(S A)$. Data are means, error bars $=$ SEM.

In all three groups of patients, blood samples were taken at the time of coronary angiography, before injection of the contrast medium. Cardioactive drugs-including nitrates, $\beta$ blocking agents, and aspirin-were not discontinued at the time of the study. However, patients with intercurrent inflammatory conditions and those taking non-steroidal antiinflammatory drugs or steroids were excluded.

\section{CORONARY ANGIOGRAPHY}

All patients underwent coronary angiography by the Judkins technique. Left ventricular angiography was performed in the $30^{\circ}$ right anterior oblique projection. End systolic and end diastolic ventricular volumes and left ventricular ejection fraction were calculated by the standard area-length method. Significant coronary artery disease was defined as lumen diameter narrowing of more than $50 \%$ in at least one major epicardial coronary artery. Among the patients with unstable angina, four were studied within 48 hours of admission, while the other 25 had coronary arteriography at a mean of 5.1 days after admission (range 3-9 days).

MCP-1 and to correlate them with troponin $\mathrm{T}$ concentrations in patients with both stable and unstable angina.

\section{Methods}

PATIENTS

The study population included 76 patients admitted to our clinic for cardiac evaluation. Group 1 was composed of 29 patients with unstable angina, admitted to the coronary care unit because of chest pain at rest associated with transient ST segment changes but without enzymatic evidence of ongoing myocardial infarction (classes B and C of the Braunwald classification). ${ }^{26}$ All patients were given full medical treatment, including intravenous heparin and glyceryl trinitrate. Nine of these patients were secondary referrals to our centre. Group 2 included 28 patients with stable exercise induced angina, confirmed by a positive exercise test result (the development of horizontal or downward ST segment depression of $\geqslant 1 \mathrm{~mm}$ ). Group 3 was formed of 19 control subjects with angiographically normal coronary arteries who underwent cardiac catheterisation for reasons other than cardiac ischaemia. The final diagnosis in these patients was mitral or aortic valve disease in 17 and dilated cardiomyopathy in two.

\section{LABORATORY INVESTIGATION}

Aliquots of blood from each patient were collected in test tubes containing EDTA. Plasma was separated by centrifugation and then frozen at $-80^{\circ} \mathrm{C}$.

Quantitative measurements of interleukin 6 and interferon $\gamma$ were performed using an enzyme linked immunosorbent assay (ELISA) with a microtitre plate precoated with the specific monoclonal antibody (Bender MedSystem, Vienna, Austria). Tests were performed according to the supplier's instructions. Samples and standards were assayed simultaneously in duplicate. The sample volume used for interleukin 6 and interferon $\gamma$ was $50 \mu$ l. None of the samples was diluted. The standard curve range for interleukin 6 was $1.6-100 \mathrm{pg} / \mathrm{ml}$ and for interferon $\gamma, 1.5-100 \mathrm{pg} / \mathrm{ml}$. The sensitivity of the assay was $0.6 \mathrm{pg} / \mathrm{ml}$ for interleukin 6 and $0.30 \mathrm{pg} / \mathrm{ml}$ for interferon $\gamma$. The overall intraassay coefficient of variation was $3.4 \%$ for interleukin 6 and $5.7 \%$ for interferon $\gamma$; the overall interassay coefficients of variation were $5.2 \%$ and $5.7 \%$.

Quantitative measurement of MCP-1 was performed by ELISA, using a DuoSet kit (R\&D System, Edinburgh, UK) with monoclonal antibodies for capture and detection. Samples and 


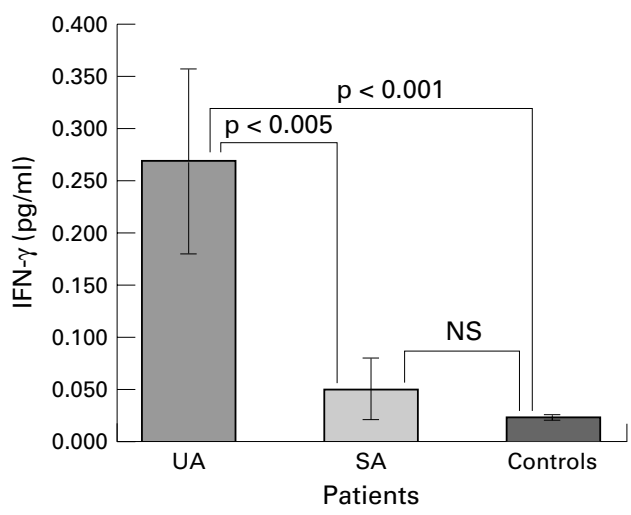

Figure 2 Interferon $\gamma($ IFN- $\gamma)$ concentrations were higher in unstable angina (UA) than in stable angina $(S A)$ or controls. There was no difference between stable angina and controls. Data means, error bars = SEM.

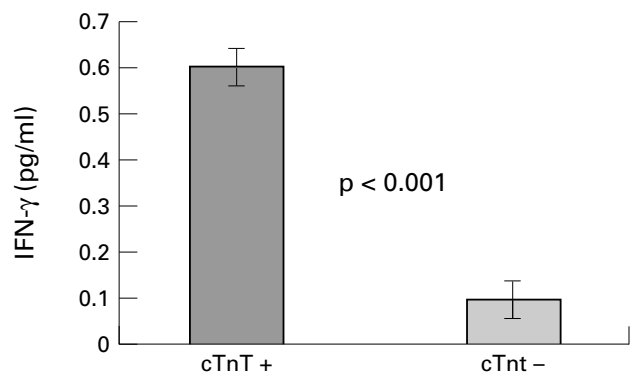

Figure 3 Among patients with unstable angina, those with positive cardiac troponin $T(c T n T+)$ had significantly higher concentrations of interferon $\gamma($ IFN- $\gamma$ ) than those with negative troponin $T$ (cTnT-). Data means, error bars $=$ SEM.

standards were assayed simultaneously in duplicate. The sample volume used was $50 \mu \mathrm{l}$. None of the samples was diluted. The standard curve range was $15.6-1000 \mathrm{pg} / \mathrm{ml}$. The sensitivity of the assay was $3.4 \mathrm{pg} / \mathrm{ml}$. The overall intra-assay and interassay coefficients of variation were $2.9 \%$ and $4.8 \%$, respectively.

Serum troponin $\mathrm{T}$ was measured by an electrochemiluminescence immunoassay (ECLIA), using the Elesys 2010 system (Roche Diagnostic, Basel, Switzerland). The intraassay coefficient of variation was $5 \%$ and the interassay variability $7 \%$. The lower limit of detection was $0.01 \mathrm{ng} / \mathrm{ml}$ and the diagnostic cut-off point was $0.1 \mathrm{ng} / \mathrm{ml}$.

The study was approved by the institutional ethics committee for human subjects. Informed consent was obtained from all patients.

\section{STATISTICAL ANALYSIS}

Results are expressed as median and range. The non-parametric one way Kruskal-Wallis test was used to investigate differences among the three groups of patients at each time point. The Mann-Whitney test for unpaired data was used for comparison of data between patients with unstable angina and those with stable angina. Two tailed probability values of $\mathrm{p}<0.05$ were considered significant.

\section{Results}

Clinical and angiographic characteristics of the patients are given in table 1 . Interleukin 6 was increased in group 1 (unstable angina) compared with group 3 (control): group 1, mean

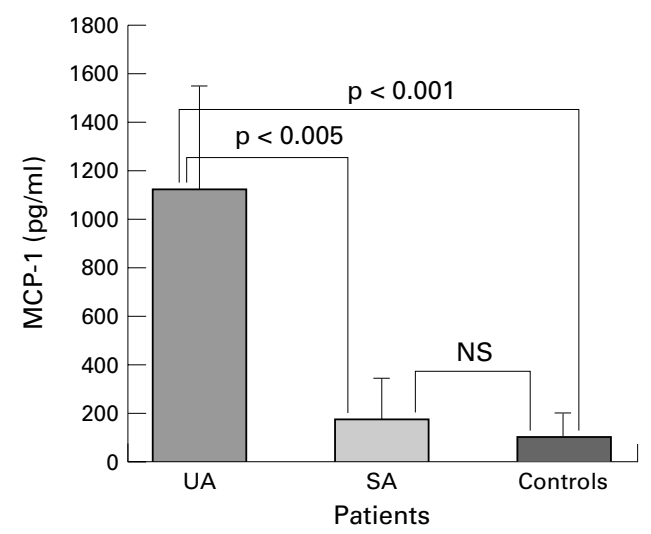

Figure 4 Monocyte chemotactic protein-1 (MCP-1) concentrations were higher in unstable angina (UA) than in stable angina ( $S A)$ or controls. There was no difference between stable angina and controls. Data means, error bars $=$ SEM.

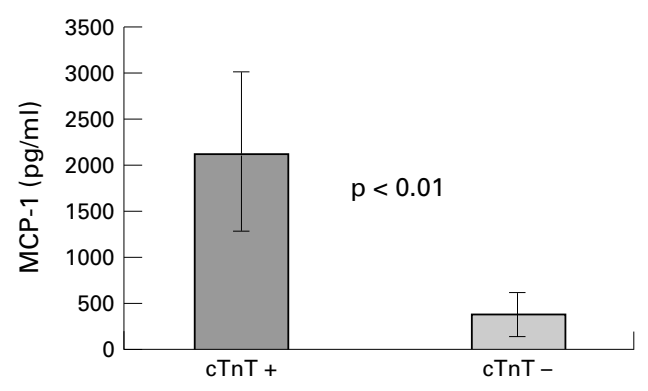

Figure 5 Monocyte chemotactic protein-1 (MCP-1) concentrations were higher in unstable angina (UA) patients with positive cardiac troponin $T(c T n T+)$ than in those with negative troponin $T$ (cTnT-). Data means, error bars $=$ SEM.

2.19 (range $0.53-50.84$ ) $\mathrm{pg} / \mathrm{ml}$; group $2,1.81$ (0.66-48.93) pg/ml; group 3, $1.62 \quad(0.79-$ 3.98) $\mathrm{pg} / \mathrm{ml} ; \mathrm{p}<0.005$ group $1 v$ group 3 (fig 1).

Interferon $\gamma$ was higher in the group 1 than in the other two groups: group 1, 0 (0$5.51) \mathrm{pg} / \mathrm{ml}$; group $2,0(0-0.74) \mathrm{pg} / \mathrm{ml}$; group $3,0(0-0.37) \mathrm{pg} / \mathrm{ml} ; \mathrm{p}<0.005$ and $\mathrm{p}<0.001$, respectively (fig 2 ). Among the 29 patients with unstable angina, 11 with raised troponin $\mathrm{T}$ concentrations had significantly higher plasma interferon $\gamma$ than the 18 without a raised troponin T: $0(0-5.51) \mathrm{pg} / \mathrm{ml} v 0(0-060) \mathrm{pg} /$ $\mathrm{ml}(\mathrm{p}<0.001)$ (fig 3$)$. On the other hand, no difference was found in plasma interleukin 6 concentrations in patients with unstable angina between those with raised and those with normal plasma troponin $\mathrm{T}: 2.89$ (1.04 to 13.56$) v$ 1.90 (0.53 to 15.84$) \mathrm{pg} / \mathrm{ml}$.

Plasma MCP-1 concentrations were also higher in the patients with unstable angina than in those with stable angina or in the controls: group 1, 267 (6-8670) pg/ml; group 2, 134 (19-89) $\mathrm{pg} / \mathrm{ml}$; group 3, 84.5 (5-325) $\mathrm{pg} / \mathrm{ml}$; $\mathrm{p}<0.005$ and $\mathrm{p}<0.001$, respectively (fig 4). Patients with unstable angina and a raised plasma troponin $\mathrm{T}$ had higher plasma MCP-1 concentrations than those with no increase in troponin T: $53(14.5-8670) \mathrm{pg} / \mathrm{ml} v 69$ (6-3333) $\mathrm{pg} / \mathrm{ml} ; \mathrm{p}<0.01$ (fig 5).

In the patients with unstable angina differences were found in interleukin 6, interferon $\gamma$, and MCP-1 values depending on whether or 
Table 2 Interleukin 6 (IL-6), interferon $\gamma(I F N-\gamma)$, and monocyte chemotactic protein-1 (MCP-1) values in patients with unstable angina who did or did not have chest pain in the 48 hours preceding coronary arteriography

\begin{tabular}{lll}
\hline & $\begin{array}{l}\text { Chest pain within } \\
\text { 48 hours }(n=10)\end{array}$ & $\begin{array}{l}\text { No chest pain within } \\
\text { 48 hours }(n=19)\end{array}$ \\
\hline $\mathrm{IL}-6(\mathrm{pg} / \mathrm{ml})$ & $2.83(2.19-4.23)$ & $2.16(0.53-50.84)$ \\
$\mathrm{IFN}-\gamma(\mathrm{pg} / \mathrm{ml})$ & $0(0-0.47)$ & $0(0-5.51)$ \\
$\mathrm{MCP}-1(\mathrm{pg} / \mathrm{ml})$ & $257(44-1746)$ & $196(6-8670)$ \\
\hline
\end{tabular}

Values are median (range).

not they had had chest pain in the 48 hours preceding coronary arteriography (table 2 ).

\section{Discussion}

Inflammation is well recognised as a pathogenic component of unstable angina. ${ }^{210}$ Inflammatory mediators as well adhesion molecules of neutrophils and monocytes have been shown to be increased in the plasma of patients presenting with acute coronary syndromes.

INTERLEUKIN 6, INTERFERON $\gamma$, AND MCP-1 IN UNSTABLE ANGINA

Interleukin 6, a proinflammatory cytokine with stimulatory effects on $\mathrm{T}$ and $\mathrm{B}$ lymphocytes, induces the synthesis of acute phase proteins such as $\mathrm{C}$ reactive protein and fibrinogen. Biasucci and colleagues found that interleukin 6 was increased in $61 \%$ of patients with unstable angina, compared with $21 \%$ of patients with stable angina. ${ }^{16}$ Increasing concentrations of interleukin 6 were also found to be associated with a complicated clinical course in unstable angina.

Interleukin 6 is the major determinant of the liver production of acute phase proteins through direct stimulation of hepatocytes. ${ }^{16}$ Raised concentrations of C reactive protein, a prototypical acute phase reactant, are also associated with an unfavourable outcome. ${ }^{17}$ In the TIMI (thrombolysis in myocardial infarction) $11 \mathrm{~A}$ substudy, ${ }^{18}$ the relation between $\mathrm{C}$ reactive protein concentrations and the qualitative result of a rapid troponin $\mathrm{T}$ assay was determined in 437 patients with unstable angina and non-Q wave myocardial infarction. The probability of a positive rapid troponin $\mathrm{T}$ rose significantly with increasing $\mathrm{C}$ reactive protein concentrations. However, $20 \%$ of patients with a negative rapid troponin $\mathrm{T}$ assay had raised $\mathrm{C}$ reactive protein. Our data show that interleukin 6 was increased in patients with unstable angina in comparison with a control group of patients without coronary artery disease. Although patients with unstable angina had higher values than those with stable angina, the difference between these two groups was not significant. Moreover, in patients with unstable angina no correlation was found between interleukin 6 concentrations and increased troponin $\mathrm{T}$ values.

MCP-1, a major chemotactic molecule secreted in the vessel wall, is predominantly found in macrophage-rich areas of atherosclerotic lesions. Gawatz and colleagues studied the secretion of MCP-1 by human umbilical endothelial cells incubated with nonstimulated or ADP activated platelets for six hours. ${ }^{27}$ They found that activated platelets induced endothelial secretion of MCP-1, whereas significantly less secretion occurred in the presence of non-stimulated platelets, implying that an activation dependent release of platelet derived products stimulates MCP-1 production, favouring the migration and entrapment of monocytes - an early step in the atherogenesis and restenosis process. In a preliminary report, Nakamura and colleagues measured MCP-1 concentrations in 15 patients with acute myocardial infarction, 30 with stable angina, and 19 controls. ${ }^{28}$ These investigators found increased concentrations of this chemotactic protein in patients with acute myocardial infarction compared with the other two groups. As particularly high MCP-1 concentrations were found in patients with preinfarction angina, they concluded that monocytes may play an important role in plaque rupture. In our study, we observed much higher concentrations of MCP-1 in patients with unstable angina than in the other two groups, and a significant correlation with a positive troponin $\mathrm{T}$.

Similarly, interferon $\gamma$ concentrations were also significantly higher in patients with unstable angina than in the other two groups. Moreover, in the unstable angina group, patients with a positive troponin $\mathrm{T}$ assay had higher interferon $\gamma$ values than those with a negative troponin $\mathrm{T}$. Interferon $\gamma$ is a potent immunostimulatory cytokine secreted by $\mathrm{T}$ lymphocytes, which promotes atherosclerosis through local effects in the arterial wall as well as through a systemic effect on plasma lipoproteins. Moreover, this cytokine greatly decreases the ability of human smooth muscle cells to express the interstitial collagen genes and can also contribute to activating the apoptosis programme in human vascular smooth muscle cells. Inhibition of interstitial collagen synthesis and impaired muscle cell growth in the fibrous cap of the atherosclerotic lesion may destabilise vulnerable regions of the plaque, rendering them weak and prone to rupture.

\section{CORRELATION BETWEEN INFLAMMATORY} MARKERS AND TROPONIN T

The correlation of high concentrations of MCP-1 and interferon $\gamma$ with a positive troponin $\mathrm{T}$ assay is intriguing. About $20-40 \%$ of patients with unstable angina are reported to have detectable troponin $\mathrm{T}$ in the serum. Circulating troponin $\mathrm{T}$ is a marker of minor myocardial injury and is associated with an increased risk of serious cardiac events in this condition. This marker of myocardial injury may be raised in the absence of other signs of myocardial infarction. It is controversial whether this reflects microinfarcts or reversible myocardial damage.$^{20}$ It has been hypothesised that high serum concentrations of troponin $\mathrm{T}$ or I reflect an active thrombotic process with distal embolisation of platelet thrombi originating from the culprit lesion. ${ }^{29}$ Recent data from the CAPTURE trial (c7E3 Fab antiplatelet therapy in unstable refractory angina) show that antithrombotic treatment with high doses of glycoprotein IIb/IIIa receptor blockers 
significantly reduces the rate of myocardial infarction before as well as during coronary angioplasty in patients with refractory unstable angina and raised troponin $\mathrm{T}$ concentrations. ${ }^{29}$ It has also been shown that enhanced activation of coagulation is present in patients with troponin $\mathrm{T}$ positive unstable angina. Terres and colleagues studied 22 patients with angiographically documented coronary heart disease and unstable angina at rest $^{30}$ : in nine patients with increased maximum serum troponin $T$ value, the maximum concentrations of fibrin monomers during the first 48 hours were higher than in patients with persistently normal troponin $\mathrm{T}$. The investigators concluded that enhanced activation of coagulation in patients with troponin $\mathrm{T}$ positive unstable angina may contribute to the adverse outcome associated with this condition.

It is possible that the greatly raised concentrations of MCP-1 and interferon $\gamma$ observed in patients with unstable angina and positive troponin $\mathrm{T}$ are secondary to myocardial cell damage. Alternatively, it is conceivable that the increased concentrations of MCP-1 and interferon $\gamma$ are related to the mechanism of plaque rupture and thrombus formation.

\section{CONCLUSIONS}

MCP-1 and interferon $\gamma$ concentrations are specifically increased in patients with unstable angina, particularly in those with a positive troponin $T$ assay, suggesting a probable relation to myocardial cell damage or plaque rupture with thrombus formation. Further studies should clarify the time course of MCP-1 and interferon $\gamma$ concentrations in unstable angina and their prognostic value.

1 Ross R. Mechanisms of disease: atherosclerosis, an inflammatory disease. N Engl 7 Med 1999;340:115-26.

2 Shah PK. New insights into the pathogenesis and prevention of acute coronary syndromes. Am $\mathcal{f}$ Cardiol 1997; 79: tion of

3 Kulkielka GL, Smith CW, Maning AM, et al. Induction of interleukin synthesis in the myocardium. Circulation 1995 interleukin synt

4 Neri Serneri GG, Abbate R, Gori AN, et al. Transient intermittent lymphocyte activation is responsible for the instability of angina. Circulation 1992;86:790-7.

5 Mazzone A, De Servi S, Ricevuti G, et al. Increased expression of neutrophil and monocyte adhesion molecules in unstable coronary artery disease. Circulation 1993;88:35863.

6 Haught WH, Mansour M, Routhlein R, et al. Alteration in circulating intercellular adhesion molecule-1 and L-selectin; further evidence for chronic inflammation in ischemic heart disease. Am Heart f 1996;132:1-6.

7 Barath P, Fishbein MC, Cao J, et al. Detection and localization of TNF in human atheroma. Am f Cardiol 1989;21: 1241-51.

8 Vaddi K, Nicolini FA, Metha P, et al. Increased secretion of tumor necrosis factor-alpha and interferon-gamma by mononuclear leukocytes in patients with ischemic heart disease: relevance in superoxide anion generation. Circuladisease: relevance in

9 Mendall MA, Patel P, Asante M, et al. Relation of serum cytokine concentrations to cardiovascular risk factors and coronary artery disease. Heart 1997;78:273-7.

10 Libby P. Molecular bases of the acute coronary syndromes. Circulation 1995;91:2844-50.

11 Rab ST, Alexander RW, Ansari AA. Evidence for activated circulating macrophages/monocytes in unstable angina. $f$ Am Coll Cardiol 1990;79:549-56.

12 Dinerman JL, Metha JL, Saldeen TG, et al. Increased neutrophil elastase release in unstable angina pectoris and acute myocardial infarction. F Am Coll Cardiol 1990;15: 1559-63.

13 Ott I, Neumann FJ, Gawaz M, et al. Increased neutrophilplatelet adhesion in patients with unstable angina. Circulaplatelet adhesion in pa

14 Biasucci LM, D’Onofrio G, Liuzzo G, et al. Intracellular neutrophil myeloperoxidase is reduced in unstable angina and acute myocardial infarction, but its reduction is not related to ischemia. $7 \mathrm{Am}$ Coll Cardiol 1996;27:611-16.

15 De Servi S, Mazzone A, Ricevuti G, et al. Expression of neutrophil and monocyte CD11B/CD18 adhesion molecules at different sites of the coronary tree in unstable angina pectoris. Am $\mathcal{F}$ Cardiol 1996;78:565-8.

16 Biasucci LM, Vitelli A, Liuzzo G, et al. Elevated levels of interleukin-6 in unstable angina. Circulation 1996;94:874-

17 Liuzzo G, Biasucci LM, Gallimore JR, et al. The prognostic value of C-reactive protein and serum amyloid protein in value of C-reactive protein and serum amyloid protein in

18 Morrow DA, Rifai N, Antman EM, et al. C-reactive protein is a potent predictor of mortality independently of and in ombination with troponin $\mathrm{T}$ in acute coronary syndromes: a TIMI 11A substudy. F Am Coll Cardiol 1998;31:1460-5

19 Rebuzzi AG, Quaranta G, Liuzzo G, et al. Incremental prognostic value of serum levels of troponin $\mathrm{T}$ and C-reactive protein on admission in patients with unstable angina pectoris. Am $\mathcal{F}$ Cardiol 1998;82:715-19.

20 Benamer H, Steg PG, Benessiano J, et al. Comparison of the prognostic value of C-reactive protein and troponin I in patients with unstable angina pectoris. Am F Cardiol 1998; 82:845-50.

21 Ridker PM, Cushnan M, Stamofer MJ, et al. Inflammation, aspirin, and the risk of cardiovascular disease in apparently healthy men. N Engl f Med 1997;336:973-9.

22 Haverkate F, Thompson SG, Pyke S, et al, for the European Concerted Action on Thrombosis and Disabilities Angina Pectoris Study Group. Production of C-reactive protein and risk of coronary events in stable and unstable angina. and risk of coronary eve

23 Fitzgerald DJ, Roy L, Catella F, et al. Platelets activation in unstable coronary artery disease. N Engl f Med 1986;315: 983-9.

24 van der Wal AC, Becker AE, van der Loos CM, et al. Site of intimal rupture or erosion of thrombosed coronary atherosclerotic plaques is characterized by an inflammatory process irrespective of the dominant plaque morphology. Circulation 1994;89:36-44.

25 Schratzberger P, Dunzendorfer S, Reinisch N, et al. Release of chemoattractants for human monocytes from endothelial cells by interaction with neutrophils. Cardiovasc Res 1998;38:516-21.

26 Braunwald E. Unstable angina: a classification. Circulation 1989;80:410-14.

27 Gawaz M, Neumann FJ, Dickfeld T, et al. Activated platelets induce monocyte chemotactic protein-1 secretion and surface expression of intercellular adhesion mol

28 Nakamura S, Saito T, Oshima S, et al. Serial changes of monocyte chemoattractant protein-1 (MCP-1) in acute myocardial infarction [abstract]. $\mathcal{F} \mathrm{Am}$ Coll Cardiol 1999;33:385A.

29 Hamm CW, Heeschen C, Goldmann B, et al, for the c7E3 Fab Antiplatelet Therapy in Unstable Refractory Angina (CAPTURE) Study Investigators. Benefit of Abiciximab in patients with refractory unstable angina in relation to serum troponin T levels. $N$ Engl f Med 1999;340:1623-9.

30 Terres W, Kummel P, Sudrow A, et al. Enhanced coagulation activation in troponin T-positive unstable angina pectoris. Am Heart $\mathcal{f}$ 1998;135:281-6. 